\title{
The aging male project
}

\author{
Farid Saad
}

\begin{abstract}
Abstrak
Dengan peningkatan umur harapan hidup dan penurunan angka reproduksi, struktur kependudukan berubah. Program penelitian dan pengembangan Jenapharm menyelidiki pria usia lanjut. Pada pria, dapat diobservasi penurunan produksi steroid seks dan hormon lainnya berhubungan dengan penuaan. Pola khusus ritmisitas harian menjadi agak lebih kurang jelas. Ini merupakan sebagian dari gambaran yang kompleks di mana tidak hanya terlibat hormon yang terisolasi, tetapi juga pengaruh hormon satu dengan lainnya. Banyak faktor lingkungan luar dan dalam diperantarai oleh neurotransmiter yang secara konstan mempengaruhi keseimbangan hormon yang sangat sensitif. Karena itu penuaan juga didefinisikan sebagai "disfungsi bertahap proses homeostasis". Penununan kadar testosteron $(T)$ terlibat dalam gejala "andropause" pada pria: hilangnya libido, disfungsi ereksi, resisten reseptor insulin, kegemukan, osteoporosis, gangguan metabolisme lipid, gangguan miokardium dan sirkulasi, gangguan kenyamanan dan perasaan. Data dihimpun dari penelitian pengobatan pria hipogonad dengan $T$ pengganti. Pada pasien ini yang diberi pengobatan $T$ maka libido meningkat, penurunan massa lemak, penguatan otot, peningkatan mineral tulang dan eritropoiesis. Apakah gejala andropausa pada usia lanjut dapat berhasil diobati dengan substitusi T masih diselidiki. Pengaruh negatif $T$, terutama terhadap prostat dan sistem kardiovaskuler, dibicarakan. Terdapat kejadian bahwa kadar T rendah nampaknya menjadi resiko terhadap prostat dan sistem kardiovaskuler. Formulasi testosteron undekanoat baru Jenapharm untuk penyuntikan intramuskuler dapat diberikan setiap tiga bulan. Kadar $T$ darah tetap dalam kisaran fisiologis. Tidak terjadi puncak suprafisiologik. Pada wanita, esirogen mempunyai pengaruh non-genitalia yang menguniungkan. Penelitian dengan konsentrasi pada estrogen sintetik untuk pria tanpa sifat feminisasi seperti ginekomastia dan pengurangan ukuran testis. Beberapa derivat 17 alfa estradiol telah disintesis beberapa menunjukkan secara selektif untuk sistem syaraf pusat. Pengaruh SSP telah ditunjukkan pada wanita dan binatang jantan. Proteksi terhadap kardiovaskuler telah ditunjukkan pada penelitian binatang dan manusia Ukuran plaq aterosklerosis berkurang setelah penyuntikan estrogen pada kelinci yang diberi makan kolesterol. Monyet yang diberi makan fitoestrogen mempunyai kolesterol total dan kolesterol LDL lebih rendah. Sebagian lesi aterosklerosis, reaktifitas pembuluh darah arteri koroner diperbaiki. Beberapa penemuan eksperimen ini telah dikonfirmasi pada penelitian manusia pada wanita pảsca menopausa dengan dan tanpa pengobatan estrogen. Apakah semua gambaran pengaruh estrogen dapat terlihat pada pria masih diselidiki. (Med J Indones 2001; 10: 127-33)
\end{abstract}

\begin{abstract}
With an increasing life expectancy and a decreasing reproduction rate, the population structure changes. A Jenapharm $R \& D$ program investigates the endocrinology of aging men. In men, a decrease in production of sex steroids and other hormones with age can be observed. The typical patterns of daily rhythmicity become less distinct. This is part of a very complex picture in which not only isolated hormones are involved, but also the influence of hormones on each other. Many factors from the external and internal environment mediated by neurotransmitters constantly affect the highly sensitive hormonal balance. Therefore, aging has also been defined as "the gradual dysfunction of homeostatic processes". Declining testosterone (T) levels are involved in "andropausal" symptoms in men: loss of libido, erectile dysfunction, insulin receptor resistance, obesity, osteoporosis, disturbances of lipid metabolism, myocardial and circulatory disturbances, impaired well-being and mood. Data are derived from studies in hypogonadal men treated by $T$ replacement. In such patients under $T$ treatment libido increases, fat mass decreases, muscle strenth, bone mineral density and erythropoesis increase. Whether the symptoms of andropause in aging men could successfully be treated by $T$ substitution remains to be investigated. Negative effects of $T$, especially on the prostate and the cardiovascular system, are under discussion. There is increasing evidence that low T levels seem to be a risk factor for both the prostate and the cardiovascular system. Jenapharm's new testosterone undecanoate formulation for intramuscular injection can be administered every three months. T levels remain within the physiologic range. No supraphysiologic peaks occur. In women, estrogens have beneficial non-genital effects. Studies concentrate on synthetic estrogens for men without feminizing properties such as gynecomastia and reduced testicular size. Several derivatives of 17alpha estradiol have been synthesized some of which show selectivity for the central nervous system. CNS effects have been demonstrated in female and male animals. Cardiovascular protection by estrogens has been shown in animal and human studies. Atherosclerotic plaque size was reduced after estrogen injections in cholesterol-fed rabbits. Phytoestrogen-fed monkeys had lower toral cholesterol and $L D L$ cholesterol and higher HDL cholesterol. Apart from atherosclerotic lesions, coronary artery vascular reactivity was improved. Some of ihese experimental findings were confirmed in human studies in postmenopausal women with and without estrogen ireamen: Whetter all of the described estrogenic effects can be seen in men remains to be investigated. (Med $J$ Indones 2001; 10: 127-33)
\end{abstract}

Keywords: aging, andropause, testosierone, estrogens

Research and Development ar Jenapham. Jena. Germany 
With an increasing life expectancy and a decreasing reproduction rate, the population structure changes in a dramatic way. In 2000, we see for the first time in history an equal distribution in percentages of under $15 \mathrm{yr}$ olds and over $60 \mathrm{yr}$ olds in the developed countries. It is predicted that in Japan, for example, as soon as in 2010 more than one third of the population will be older than 60 years. According to the calculations of United Nations, the same change will occur in the less developed regions with a delay of about 50 years. The latest statistics indicate that this may happen even sooner.

For these reasons, scientific investigation of the phenomenon of aging not only from a social and financial, but also from a biological and medical point of view needs more and more attention. Jenapharm and its mother company Schering are primarily focused on the endocrine aspects of aging. Looking back at several decades of research and developmental work in the area of female menopause (leading to hormone replacement therapy, HRT), it is now our goal to learn more about the endocrinology of aging men.

In both genders, a decrease in production of sex steroids, DHEA, growth hormone, and melatonin can be observed. An anatomical equivalent is the reduction of size of the pituitary gland with age. Levels of corticosteroids remain stable. This leads to a relative hypercortisolemia. Not only total hormone production decreases but also the typical patterns of daily rhythmicity become less distinct. ${ }^{1,2}$ These findings become even more complex by the fact that the three axes of hormonal regulation involving hypothalamus, pituitary gland and target organs, influence each other. The CRH-ACTH-corticosteroid axis seems to have a suppressive effect on both the GHRH-GH-IGH I and the GnRH-FSH/LH-sex steroid axes. In addition, many effects from the external and internal environment mediated by neurotransmitters in the central nervous system constantly affect the highly sensitive hormonal balance. Therefore, aging has also been defined as "the gradual dysfunction of homeostatic processes. ${ }^{3}$

\section{TESTOSTERONE}

Declining testosterone levels are involved in a variety of symptoms in men: loss of libido, erectile dysfunction, insulin receptor resistance, abdominal obesity, osteoporosis, disturbances of the lint metabolism, myocardial and circulatory discotyeres. impaired well-being and mood. Hajur et al strmat that perceived libido improved significantly in other hypogonadal men after long-term testosteroe replacement. ${ }^{4}$ Serum testosterone concentration obese (BMI > 28) men were lower than in non-n tes (BMI < 27) subjects. ${ }^{5}$ Several investigarors showed that in hypogonadal men receiving testostertur treatment body fat decreased. At the same time, bous mineral density increased. ${ }^{6}$ Thus. testosteroure replacement in hypogonadal men is of crucial importance in the prevention of osteoporosis and the postponement of the fracture threshold within the life span.

Although the symptoms of andropause may not tr exclusively testosterone dependent, testosterone flys a crucial role. It would certainly be too soon to tra the conclusion that therapeutic administration of testosterone can improve or cure all these symptoms Numerous studies will be necessary to prove the potential benefits of testosterone treatment in aging men

For a long time testosterone was associated witt negative effects, especially on the prostate and the cardiovascular system. This opinion needs to to revised. Testosterone does not cause prostate carcinoma but enhances the proliferation in approximately $80 \%$ of prostatic carcinomas that are already present. There is not a single case described in which testosterone replacement in hypogonadal men has caused prostatic cancer. There is no evidence that testosterone can cause growth of the porsate exceeding what is considered normal. The contracould be true because both benign prostatic hyperplasia (BPH) and prostatic cancer occur ircreasingy at an age when testosterone levels decline."

There are also new findings concerning the c-tiovascular system. Whereas it had been assumed for a long time that testosterone supports atherosctitros there is now evidence that the incidence of contaheart disease often coincides with low testostente levels. Low testosterone levels seem to be a rist tacom for both the prostate ${ }^{9}$ and the cartionascit-

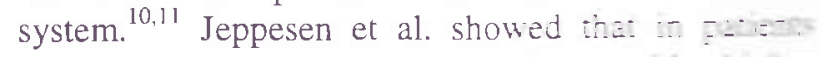
with acute ischemic stroke those a.t. testosterone levels had a better 6 months snival nat: than those with lower testosterone levels. i- - or: than a million users of androgenic anabolic serouds in the U.S. within a period of 15 years (1976 - 1940) 
only 26 cases of fatal cardiovascular events have been reported. ${ }^{13.14}$ It would definitely be too soon to come to a final conclusion but it should be kept in mind that old prejudices need to be questioned.

Different causes of the decline of testosterone levels with age have been discussed. One possible cause could be the change of intratesticular regulatory factors leading to an increased conversion of pregnenolone to progesterone instead of testosterone in the Leydig cell. Another hypothesis is a failure of appropriate GnRH secretion by the hypothalamus. ${ }^{15}$ Decreased androgenicity of physiologic serum testosterone concentrations may also lead to symptoms of andropause despite of impaired testosterone production and secretion.

Testosterone levels show very sensitive reactions to exogenous stress factors. For example, experimentally induced metabolic stress led to a significant decline of testosterone levels within less than one hour. ${ }^{16}$ Strollo et al. reported that astronauts had significantly lower testosterone levels inflight as compared to preflight. ${ }^{17}$ Even winning and losing small amounts of money in gambling had almost immediate effects on testosterone levels. ${ }^{18}$

Jenapharm is currently developing a testosterone ester for intramuscular injection, the well-known testosterone undecanoate. This formulation has major advantages compared to preparations that are currently available: It can be administered every three months with testosterone levels remaining within the physiologic range (Figure 1). There are no supraphysiologic peaks as observed with testosterone enanthate. ${ }^{19-22}$ The ups and downs of testosterone levels are held reponsible not only for mood swings that seem to be quite significant in many patients, but high peak levels may also be the reason for an elevated hematocrit.

In the near future, we will concentrate on the identification of dissociated or tissue specific androgens. These are steroids that will ideally have all of the desired androgenic properties but none of the less desired. There are already compounds which are in principle dissociated or tissue-selective androgens, e.g. anabolic androgens with a three-fold stronger effect on the muscle compared to native testosterone but with less than half of the genital effects. In addition to its selective properties, such a molecule should be orally available to avoid injections.

\section{ESTROGENS}

There are controversial results and opinions whether estrogen levels in men decline with age. Whereas some investigators claim that estrogens remain stable. ${ }^{2+27}$ more and more papers show an age-related decline in estrogen secretion.-3 Our own experience shows that the correct measurement of estrogens

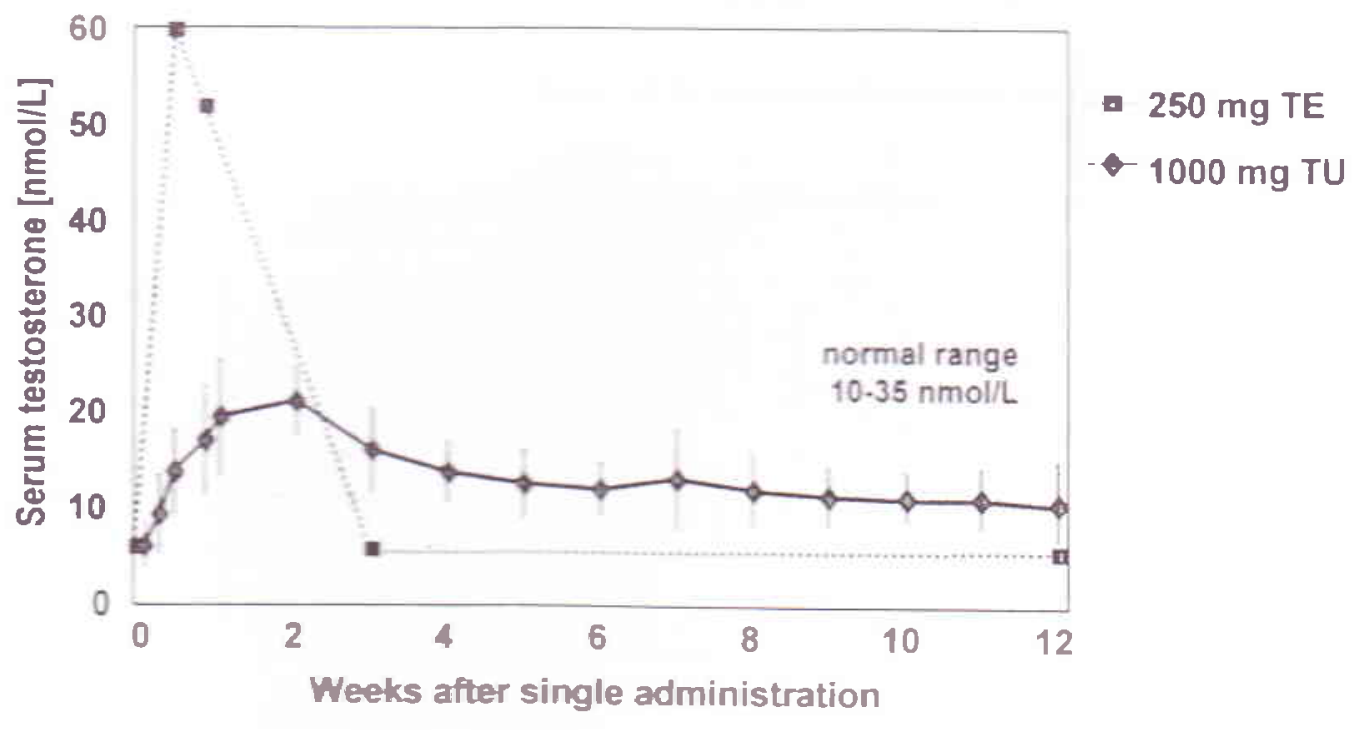

Behre HM et al. (1999)

Figure 1. Phamacoducencs of testosterone enumina:e (TE and testosterone undecanoate (TU) i.m. in hypogonadal men with basal testosierone levels $<6$ nmolL 
depends significantly on the hormone essays employed. Of the circulating estrogens in men, 75 $90 \%$ arise from peripheral aromatization, mainly in adipose tissue, of both testosterone to 17-betaestradiol $\left(\mathrm{E}_{2}\right)$ and androstenedione to estrone $\left(\mathrm{E}_{1}\right)$. The testes synthesize the remaining $10-25 \%$. $^{29}$

From the experience with hormone replacement therapy (HRT) in peri- and postmenopausal women it is well accepted that estrogens have beneficial effects on the cardiovascular system and on the central nervous system. We have established a program to investigate whether estrogens could have similar effects in the male gender. From studies as well as therapeutic experience in patients with hormonedependent prostatic carcinoma who have been treated with high doses of estrogens it is known that 'natural' estrogens such as 17-beta-estradiol can lead to feminizing effects, e.g. gynecomastia and reduction of testicular volume. Similar findings have been reported from studies in male-to-female transsexuals who also receive high doseas of estradiol. Therefore we are working with synthetic estrogen compounds that show a reduced genital effect compared to native estradiol.

A lead compound displaying this particular property is 17-alpha-estradiol. Based on this molecule we have synthesized a number of derivatives for our further studies (Figure 2 and 3). Some of these substances show a remarkable selectivity for the central nervous system. Several mechanisms of the neuroprotective functions of estrogens are being discussed: Genomic effects mediated by transcription factors, antioxidant activities, and modulation of neuronal membranes. ${ }^{30}$

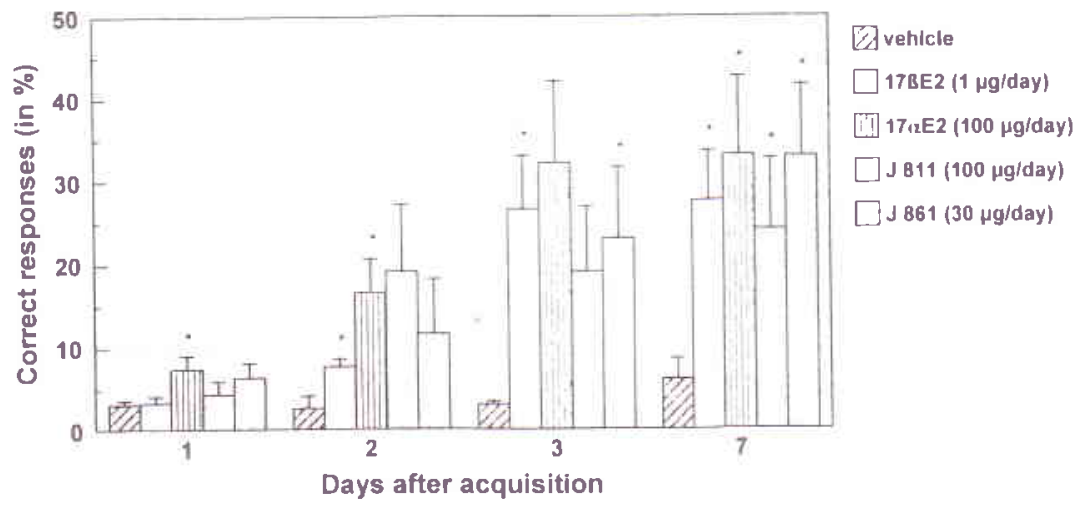

Mitev and Patchev (1997)

Figure 2. Effects of chronic estrogen administration on the retentio of conditioned avoidance behaviour in ovarectomized rats I

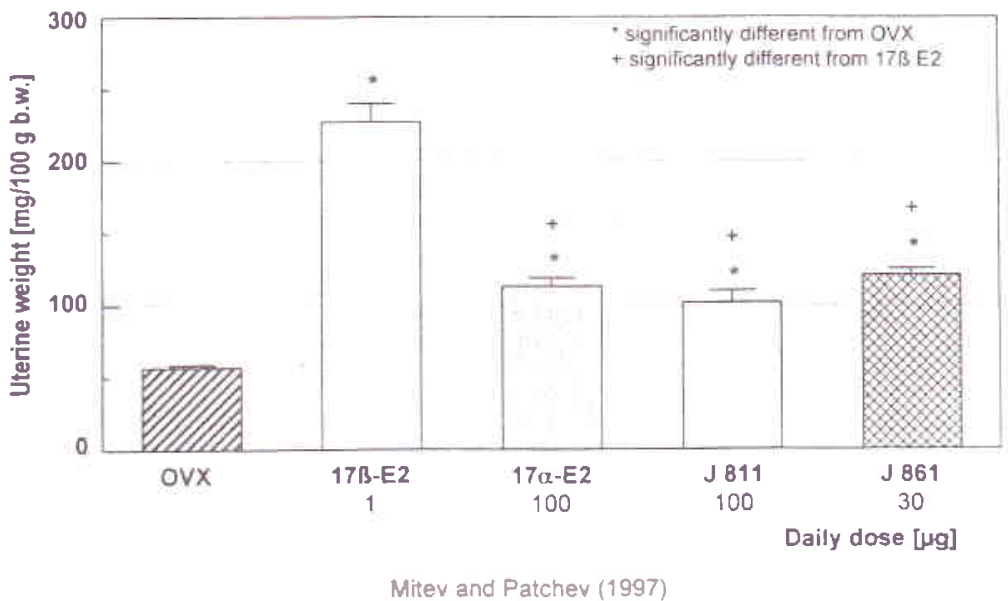

Figure 3. Effects of chronic estrogen administration on the retentio of conditioned avoidance bersu. L $^{2}$ in ovarectomized rats II 
CNS effects of estrogens have been demonstrated in vitro in dopaminergic neurons using cell cultures. Experimentally induced oxidative stress caused significant cell death which could be prevented by preincubation with both 17-beta- and 17-alphaestradiol. ${ }^{31}$ The effects of estrogens on the CNS could be shown in a number of animal experiments. for instance studies in which cognitive functions of animals including the ability to learn as well as memorise are assessed before and after estrogen treatment. ${ }^{32}$ These effects could be shown in female and male animals. Estrogen-treated male-to-female transsexuals showed improved learning scores compared to a control group awaiting treatment. ${ }^{33}$ The Max Planck Institute of Psychiatry in Munich sees several parallels between estrogens and Alzheimer's disease. ${ }^{34}$

A human model has been described by the group of Carani from Modena, Italy. They have identified a patient with an aromatase deficiency. This patient can not metabolise testosterone to estradiol. Treatment with estradiol significantly changed several psychological parameters and aspects of sexual behavior. $^{35}$

In this patient, it was also very well demonstrated that estrogens are of crucial importance for the bone. When he was diagnosed at approximately age 30 . his epiphyses were unfused. The man did not respond to testosterone treatment but to ireatment with estradiol." Other studies have demonstrated the role of estrogens in ldiogathic osteoporosis and. since most of the subjects investigated hed physologe testosterone levals but low jirogens. :t can be hypothesized that aromatase defictency of varyng degrees could be the cause

Cardiovascular provection by jirrogens has been shown in animal expertmers and human studies. Atherosclerotic plaque size was reduced after estrogen injections in cholesterol-ted ratais (Figure 4). In rabbits and monkeys. feed conaming ghytoestrogens in soy products showed the same effect. Moreover. the phytoestrogen-ted anmals had lower total cholesterol and LDL cholesterol and higher HDL cholesterol. These findings could be confirmed in humans. ${ }^{41}$

Apart from atherosclerotic lesions, coronary artery vascular reactivity (vasodiatation) was improved in estrogen-fed monkeys. $\div 2$ Some of these experimental findings were confirmed in human studies in postmenopausal women ${ }^{43}$ and men $^{44}$ with and without estrogen treatment. Again, different possible mechanisms of rapid vasomotor effects of estrogens are being discussed: (1) nonreceptor mediated effects such as direct effects of E2 on membrane function or ion channels; (2) effects mediated by a novel, as yet undescribed estrogen receptor; and (3) effects mediated by one or both of the classical Ers acting in a novel manner. ${ }^{45}$

More recently, musculoprotective effects of estrogens have been described in animal experiments in rats. ${ }^{46,47}$ From in vitro studies in peripheral blood mononuclear cells, a stimulatory effect of estrogens on immunoglobulin production has been reported. ${ }^{48}$

Whether all of the described estrogenic effects can be seen in men remains to be investigated. We hope to be able to start our first human studies with nonfeminizing estrogens within the next two years.

\section{REFERENCES}

1. Copinschi G and Van Cauter E. Effects of ageing on modulation of homonal secretions by sleep and circadian rhythmicity. Horm Res 1995; 43:20-4

2. Rosén T, Johannsson G. Bengtsson B.A. Consequences of growth hormone deficiency in adults, and effects of growth hormone replacement therapy. Acta Paediatr Suppl. 1994: 399: $21-4$

3. Svec F. Ageing and adrenal cortical function. Baillière's Clincal Endocrinology and Metabolism, 11 (2):271-87, 1997.

4 Hajjar R, Kaiser F, Morley J. Outcomes of long-term testosterone replacement in older hypogonadal males: A retrospective analysis. JCEM 1997: 82 (11):3793-6.

5. Pasquali R. Macor C. Vicennati V. Novo F. De lasio R. Mesini P. Boschi S. Casimirri F, Vettor R. Effects of acute hyperinsulinemia on testosterone serum concen-trations in adult obese and normal-weight men. Metabolism 1997; 46 (5) $526-9$

6. Katznelson L, Finkelstein J, Schoenfeld D, Rosenthal D, Anderson E, Klibanski A. Increase in bone density and lean body mass during testosterone administration in men with acquired hypogonadism. JCEM 1996; 81 (12):4358-65.

7. Ziegler R, Scheidt-Nave C, Scharla S. Pathophysiology of osteoporosis: Unresolved problems and new insights. J Nutr 1995; 125:2033S-2037S.

8. Hsing A. Tsao L, Devesa S. International trends and patterns of prostate cancer incidence and mortality. Int J Cancer 2000; 85:60-7.

9. Comhaire F. Andropause: Hormone replacement therapy in the ageing male. In press.

10. Phillips G. Pinkemell B. Jing T-Y. The association of hypotestoteronemia with coronary artery disease in men. Arterioscler Thromb 1994; 14:701-6. 
11. Zmunda J, Cauley J, Kriska A, Glynn N, Gutai J, Kuller L. Longitudinal relation between endogenous testosterone and cardiovascular disease risk factors in middle-aged men. Am J Epidemiol 1997; 146 (8):609-17.

12. Jeppesen L, Jorgensen $H$, Nakayama $H$, Raaschou $H$, Skyhoj T, Winther K. Decreased serum testosterone in men with acute ischaemic stroke. Arterioscler Thromb Vasc Biol 1996; 16: 749-54.

13. Rockhold R. Cardiovascular toxicity of anabolic steroids, Ann Rev Pharmacol Toxicol 1993; 33: 497-520.

14. Bagatell $\mathrm{C}$ and Bremmer W. Androgens in men - uses and abuses. NEJM 1996; 334 (11): 707-14.

15. Morley J and Perry H. Androgen deficiency in aging men. Med Clin North Amer 1999; 83 (5):1279-89.

16. Elman I and Breier A. Effects of acute metabolic stress on plasma progesterone and testosterone in male subjects: Relationship to pituitary-adrenocortical axis activation. Life Sciences 1997; 61 (17):1705-12.

17. Strollo F, Riondino G, Harris B, Strollo G, Casarosa E, Mangrossa N, Ferretti C, Luisj M. The effect of microgravity on testicular androgen secretion. Aviat Space Environ Med 1998; 69 (2): 133-6.

18. McCaul K, Gladue B, Joppa M. Winning, losing, mood, and testosterone. Horm Behav 1992; 26:486-504.

19. Behre H, Abshagen K, Oettel M, Hübler D, Nieschlag E Intramuscular injection of TU for the treatment of male hypogonadism phase I - studies. European Joumal of Endocrinology 1999; 140:414-9.

20. Nieschlag E, Büchter D, Eckardstein SV, Abshagen K, Simoni M, Behre H. Repeated intramuscular injections of testosterone undecanoate for substitution therapy in hypogonadal men. Clinical Endocrinology 1999; 51:757-63.

21. Christoph A, Schubert M, Oettel M, Hübler D, Emst M, Krone W, Jockenhövel F. The new androgen substitution therapy with intramuscular testosterone undecanoate (TU) is as efficient as the standard regime with notably fewer injections. Experim Clin Endocrinol Diab 2000, 108 (Suppl 1): S 177 (Abstract).

22. Eckardstein SV, Büchter D, Nieschlag E. Successful treatment of male hypogonadism with testosterone undecanoate (TU) injections in extended intervals of 6 to 12 weeks. Experim Clin Endocrinol Diab 2000; 108 (Suppl.1): S178 (Abstract).

23. Oettel M. Estrogens and antiestrogens in the male. In: Handbook of experimental pharmacology, Springer, Berlin and Heidelberg, 1999; Vol. 135/II: 505-71.

24. Kley H, Nieschlag E, Bidlingmaier F, Kruskemper H. Possible age-dependent influence of estrogens on the binding of testosterone in plasma of adult men. Horm Metab Res 1993; 6:213-7.

25. Rubens R, Dhont M, Vermeulen A. Further studies on Leydig cell function in old age. JCEM 1974; 39:40-4.

26. Zumoff B, Strain G, Kream J, O'Connor J, Rosenfeld R, Levin J, Fukushima D. Age variation of the 24-hour mean plasma concentration of androgens, estrogens, and gonadotropins in normal adult men. JCEM 1982; 61:705-11.

27. Kaiser F, Viosca S, Morley J, Mooradian A, Davis S, Korenman. S. Impotence and aging, clinical and hormonal factors. J Am Geriatr Soc 1998; 36:511-6.

28. Ferrinj $\mathrm{R}$ and Barrett-Connor E. Sex hormones and age: $\mathrm{A}$ cross-secuonal swdy of testosterone and estradiol and

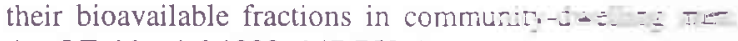
Am J Epidemiol 1998; 147:750-4.

29. Levine AC, Kirchenbaum A, Gabrilove JL Tha nat: sex steroids in the pathogenesis and manter:- = benign prostatic hyperplasia. Mt Sinai J Med $1907,-2:-$ 5.

30. Behl C and Holsboer F. The female sex hot oestrogen as a neuroprotectant. TiPS 1999: $20:-1-$

31. Sawada H, Ibi M, Kihara T, Urushitani M. A: = Shimohama S. Estradiol protects mesencephalic dop:neurons from oxidative stress-induced neuronal ist... Neurosci Res 1998; 54:707-19.

32. Packard M. Posttraining estrogen and te-n modulation. Hormon Behav 1998; 34:126-39.

33. Miles C, Green R, Sanders G, Hines M. Estrogen memory in a transsexual population. Hormon Bena, in: 34:199-208.

34. Lezoualc' $h \mathrm{~F}$ and Behl $\mathrm{C}$. The role of estrogens kappa-B in neuroprotection against oxidative stes: :Alzheimer's disease and related disorders. Will s 5. 1999.

35. Carani C, Rochira V, Faustini-Fustini M, Balestr.t $\pm c$ Granata A. Role of oestrogen in male sexual beta aInsights from the natural model of aromatase deniz:- : ? Clin Endocrinol 1999; 51:517-24.

36. Faustini-Fustini M, Rochira V, Carani C Oestrozedeficiency in men: Where are we today? Eur J Endocred 1999; 140:111-129.

37. Gillberg P, Johansson A, Ljunghall S. Decreased estrand levels and free androgen index and elevated sex hormot. binding globulin levels in male idiopathic ostecons: Calcif Tissue Int 1999; 64:209-13.

38. Huff M, Roberts D, Carroll K. Long-term effecs a: semipurified diets containing casein or soy protein :sol:-: on atherosclerosis and plasma lipoproteins in rabtis Atherosclerosis 1982; 41:327-36.

39. Anthony M, Clarkson T, Bullock B, Wagner j $5:$ protein versus soy phytoestrogens in the preventon o: diet-induced coronary artery atherosclerosis of $\ldots$ cynomolgus monkeys. Arterioscler Thromb $V_{i z 2} \equiv$. . 1997; 17:2524-31.

40. Anthony M, Clarkson T, Williams J. eftes: of isoflavones on atherosclerosis potential mect:- :J Clin Nutr 1998; 68 (supplement): 13905 - : : : $: \vdots$

41. Anderson J, Johnstone B, Cook-Newell M $\because$ :-_-1: of the effects of soy protein intake on sersm $1995 ; 333: 276-82$.

42. Honoré E, Williams J, Anthony M. Clas Z 5 isoflavones enhance vascular reactivity in amems-lo: female macaques. Fertil Steril 1997: 67: 14:-3=-

43. Riedel M, Oeltermann A, Mügge A Creng Rafflenbeul W, Lichtlen P. Vascular responses :0 1-oestradiol in postmenopausal women. Eur : C.: :$1995 ; 25: 44-7$.

44. Blumenthal R, Heldman A, Brinker J. Rzsar 1. : . . Gloth S, Gerstenblith G, Reis S. Acte enters al

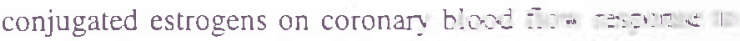

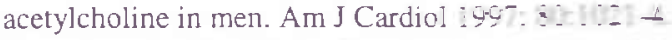

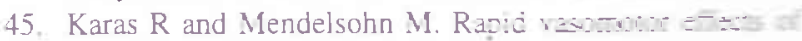
estrogen. Chest 1998: 114 (6): 1508-9 
46. Paroo Z, Tiidus P, Noble E. Estrogen attenuates HSP 72 expression in acutely exercised male rodents. Eur $\mathbf{J}$ Appl Physiol 1999; 80:180-4.

47. Tiidus $\mathrm{P}$ and Bombardier E. Oestrogen attenuates postexercise myeloperoxidase activity in skeletal muscle of male rats. Acta Physiol Scand 1999; 166: 85-90.
48. Kanda N and Tamaki K. Estrogen enhances immunoglobulin production by human PBMCs. J Allergy Clin Immunol 1999; 103 (2):282-8. 